\title{
A natural ent-kaurane diterpenoid induces antiproliferation in ovarian cancer cells via ERK1/2 regulation and inhibition of cellular migration and invasion
}

\author{
JIN SUN LEE ${ }^{1}$, MYUNG SUN LEE ${ }^{2}$, EUN YOUNG CHA ${ }^{2}$, PHUONG THIEN THUONG ${ }^{3}$, \\ JI YOUNG SUL ${ }^{1}, \mathrm{JUN}^{\mathrm{BEOM}} \mathrm{PARK}^{1}$ and YOUNG BOK KO ${ }^{4}$
}

\begin{abstract}
${ }^{1}$ Department of Surgery and Research Institute for Medicinal Sciences, Chungnam National University College of Medicine;
${ }^{2}$ Surgical Oncology Research Lab, Chungnam National University Hospital, Daejeon 35015, Republic of Korea;

${ }^{3}$ Department of Herbal Analysis and Standardization, National Institute of Medicinal Materials, Hanoi 100000, Vietnam;

${ }^{4}$ Department of Obstetrics and Gynecology and Research Institute for Medicinal Sciences,

Chungnam National University College of Medicine, Daejeon 35015, Republic of Korea
\end{abstract}

Received February 21,2018; Accepted August 2, 2018

DOI: $10.3892 / \mathrm{mmr} .2018 .9377$

\begin{abstract}
Ovarian cancer is one of the most common causes of female mortalities from gynecological tumors. An ent-kaurane diterpenoid compound CRT1 (ent-18-acetoxy-7 $\beta$-hydroxy kaur-15-oxo-16-ene), mainly isolated from the Vietnamese herb Croton tonkinesis has been used in folk medicine in Vietnam for cancer treatment. However, the effect of this compound on human ovarian cancer cells has not yet been reported. The objective of the present study was to determine the effect of CRT1 on the cell viability, apoptosis and metastasis of SKOV3 human ovarian cancer cells using a Cell Counting Kit-8 assay, flow cytometric analysis of Annexin V-fluorescein isothiocyanate/propidium iodide staining, western blot analysis, soft agar colony forming assay, wound healing assay and Matrigel invasion assay. The results revealed that CRT1 possessed significant anti-proliferative effects on SKOV3 cells. CRT1 treatment at 25 and $50 \mu \mathrm{M}$ induced apoptosis, enhanced the percentage of Annexin V-positive cells, increased the expression of pro-apoptotic protein B-cell lymphoma 2 (Bcl-2)-associated $\mathrm{X}$ protein, cytochrome $\mathrm{c}$ release from the mitochondria to the cytosol, cleaved caspase-3, caspase-7, caspase-9, and poly (adenosine diphosphate-ribose) polymerase. However, it decreased the expression of $\mathrm{Bcl}-2$ in a dose-dependent manner. The percentage of necrotic cells increased following CRT1 treatment at $<10 \mu \mathrm{M}$. CRT1 at $50 \mu \mathrm{M}$ significantly induced the phosphorylation of extracellular signal-regulated kinase
\end{abstract}

Correspondence to: Professor Young Bok Ko, Department of Obstetrics and Gynecology and Research Institute for Medicinal Sciences, Chungnam National University College of Medicine, 33 Munwha-ro, Daejeon 35015, Republic of Korea

E-mail: koyoung27@cnuh.co.kr

Key words: ovarian cancer, ent-kaurane diterpenoid, extracellular signal-regulated kinase, apoptosis, invasion, migration
(ERK). Growth inhibition and the apoptotic effects of CRT1 could be reversed by PD98059, an ERK inhibitor. Additionally, CRT1 inhibited cell migration and invasion via ERK1/2 activation in SKOV3 cells. These results indicated that CRT1, an ent-kaurane diterpenoid, may be a potential inhibitor of ovarian cancer by the activating ERK1/2/p90 ribosomal S6 kinase signaling pathway.

\section{Introduction}

Ovarian cancer is the fifth-leading cause of worldwide cancer-related deaths among woman. It accounts for more deaths than other gynecologic tumors. Standard therapy for advanced ovarian cancer consists of cytoreductive surgery followed by chemotherapy (1). The 5-year survival rate for ovarian cancer patients ranges from 30 to $92 \%$ (2). Paclitaxel-platinum treatment is the standard first-line treatment in ovarian cancer, with typical response rate of over $70 \%$. However, most patients eventually experience recurrence, with a median progression-free survival of 18 months (2). Although efforts have been focused on overcoming resistance to chemotherapy drugs for years, mortality rates of patients with ovarian cancer remain high (3).

Extracellular signal-regulating kinase (ERK) 1/2 pathway plays a major role in the survival of cancer cells via inhibition of apoptosis controlling Bcl-2 family members such as Bim, Bad, Bcl-1, and Mcl-1 (4). However, depending on cell type and stimulus, ERK1/2 activation can also mediate antiproliferative events such as apoptosis and autophagy in some studies $(4,5)$. ERK1/2 phosphorylates and activates direct downstream kinase p90 ribosomal S6 kinase (RSK). ERK1/2/p90RSK activation is involved in the progression of many cancers (6). It is emerging as a potential therapeutic target (6). The purpose of this study was to explore whether ERK1/2/p90RSK activation could mediate anticancer mechanism in ovarian cancer cells.

Croton tonkinesis Gagnep. (Euphorbiaceae), commonly known as 'Kho sam cho la (or Kho sam Bac Bo)' in Vietnamese, is a small medicinal plant indigenous to northern Vietnam (7). 
This plant has been used to treat stomach aches, abscesses, impetigoes, gastric and duodenal ulcers, and malaria (8). Crude extract of $C$. tonkinensis has shown significant cytotoxicity against breast cancer, lung cancer, and glioblastoma (9). Some ent-kaurane diterpenoids isolated from $C$. tonkinensis also possess cytotoxic and proapoptotic activities $(7,10,11)$. They can inhibit lipopolysaccharide (LPS)-induced nuclear factor- $\kappa \mathrm{B}(\mathrm{NF}-\kappa \mathrm{B})$ activation with anti-inflammatory properties $(12,13)$. They can also inhibit silent information regulator two ortholog 1 (SIRT1) and stimulate osteoblast differentiation $(14,15)$. However, the underlying mechanism by which ent-kaurane diterpenoids inhibit cancer cell growth remains controversial. Multiple signaling mechanisms, including PI3K/PKB pathway, AMP-activated protein kinase pathway, Wnt/ $\beta$-catenin pathway, and Akt/mTOR/p70S6K pathway, have been implicated in anticancer activities of this class of diterpenoids (16-20).

The objective of the present study was to investigate the effect of a natural ent-kaurane diterpenoid CRT1 isolated from C.tonkinensis on proliferation, apoptosis, migration, and invasion of human ovarian cancer cells. Molecular mechanisms associated with cellular changes were also examined in this study.

\section{Materials and methods}

Plant material and chemical isolation. The major ent-kauranoid was previously isolated from leaves of plant Croton tonkinensis and identified as ent-18-acetoxy-7 $\beta$-hydroxy kaur-15-oxo-16-ene (namely CRT1) (Fig. 1A). Purification and structure identification of CRT1 were demonstrated elsewhere (13). The purity of the compound was determined to be $97 \%$ by HPLC.

Cell culture. Human ovary adenocarcinoma SKOV3 was purchased from Korean Cell Line Bank (Seoul, Korea). McCoy's 5A, fetal bovine serum (FBS), and penicillin/streptomycin were obtained from Gibco (Thermo Fisher Scientific, Inc., Waltham, MA, USA). Trypsin/EDTA was purchased from Thermo Scientific HyClone (GE Healthcare Life Sciences, Logan, UT, USA). Cells were grown in McCoy's $5 \mathrm{~A}$ media supplemented with $10 \%(\mathrm{v} / \mathrm{v}) \mathrm{FBS}$, penicillin $(100 \mathrm{U} / \mathrm{ml}) /$ streptomycin $(100 \mu \mathrm{g} / \mathrm{ml})$ at $37^{\circ} \mathrm{C}$ in a humidified $\mathrm{CO}_{2}(5 \%)$-controlled incubator.

Cell viability assay. Cells were seeded into 96-well microplates at density of $5 \times 10^{3}$ cells $/ \mathrm{ml}$ and allowed to attach for $24 \mathrm{~h}$. CRT1 and/or PD98059 were added to the medium at various concentrations. After treatment, cell cytotoxicity and/or proliferation was assessed using Cell Counting Kit-8 (CCK-8; Dojindo Laboratories, Kumamoto, Japan). Briefly, highly water-soluble tetrazolium salt, WST-8[2-(2-methoxy-4-nitrophenyl)-3-(4-nitrophenyl)-5(2,4-disulfophenyl)-2H-tetrazolium, monosodium salt], produced an orange colored water-soluble product, formazan. The amount of formazan dye generated by dehydrogenases in cells was directly proportional to the number of living cells. CCK-8 (10 $\mu \mathrm{l})$ was added to each well and incubated at $37^{\circ} \mathrm{C}$ for $3 \mathrm{~h}$. Cell proliferation and cytotoxicity were then assessed by measuring the absorbance at wavelength of $450 \mathrm{~nm}$ using a microplate reader. Three replicated wells were used for each experimental condition.

Western blot analysis. Cells were incubated with CRT1 $(10,25$, and $50 \mu \mathrm{M})$ and/or PD98059 $(25 \mu \mathrm{g} / \mathrm{ml})$ for $24 \mathrm{~h}$, and washed twice in cold phosphate buffered saline (PBS). Cells were lysed with lysis buffer [10 mM Tris, $\mathrm{pH} 7.4$, $150 \mathrm{mM} \mathrm{NaCl}, 1 \mathrm{mM}$ EDTA, 1\% TritonX-100, 0.5\% NP-40, $1 \mathrm{mM}$ propidium iodide (PI), $1 \mathrm{mM}$ dithiothreitol (DTT), $1 \mathrm{mM}$ phenylmethylsulfonyl fluoride (PMSF)], placed on ice for $1 \mathrm{~h}$ with occasional vortexing, and centrifuged at $13,000 \mathrm{x} \mathrm{g}$ for $10 \mathrm{~min}$ at $4^{\circ} \mathrm{C}$ to collect the supernatant. Pierce BCA Assay Kit (Pierce; Thermo Fisher Scientific, Inc.) was used to determine protein concentration. Cell lysates $(50 \mu \mathrm{g})$ were subjected to sodium dodecyl sulfate (SDS)-polyacrylamide gel electrophoresis (PAGE) and transferred to polyvinylidene difluoride (PVDF) membrane. Blots were blocked with 5\% skim milk in PBS containing $0.05 \%$ Tween-20 (PBST) for $1 \mathrm{~h}$ at $25^{\circ} \mathrm{C}$ and then incubated with primary antibodies $(1: 1,000)$ overnight at $4^{\circ} \mathrm{C}$. After washing with PBST, membranes were incubated with anti-rabbit or anti-mouse horseradish peroxidase-conjugated $\operatorname{IgG}(1: 3,000)$ at room temperature for $2 \mathrm{~h}$ and visualized with enhanced chemiluminescence using Super Signal ${ }^{\circledR}$ West Pico Chemiluminescent substrate purchased from Pierce; Thermo Fisher Scientific, Inc. Antibodies to rabbit polyclonal anti-human $\operatorname{Bax}(1: 1,000$; no. 2772), rabbit polyclonal anti-human Bcl-2 (1:1,000; no. 2876), rabbit polyclonal anti-human caspase-3 (1:1,000; no. 9662), mouse monoclonal anti-human cspase-7 (1:1,000; no. 9494), rabbit polyclonal anti-human caspase-9 (1:1,000; no. 9502), rabbit polyclonal anti-human poly-(ADP-ribose) polymerase (PARP) (1:1,000; no. 9542), rabbit polyclonal anti-human phospho-p44/p42 MAPK (ERK1/2) (Thr202/Tyr204) (1:1,000; no. 9101), rabbit monoclonal anti-human RSK1/2/3 (1:1,000; no. 9355), rabbit polyclonal anti-human phospho-p90RSK (Ser380) (1:1,000; no. 9314), and rabbit polyclonal anti-human $\beta$-actin $(1: 1,000$; no. 4967) were purchased from Cell Signaling Technology, Inc. (Danvers, MA, USA). Rabbit polyclonal anti-human ERK (1:1,000; sc-94) was obtained from Santa Cruz Biotechnology, Inc. (Dallas, TX, USA). Horseradish peroxidase-conjugated anti-mouse and anti-rabbit antibodies were bought from Transduction Lab (Lexington, KY, USA). Band intensity was quantified by densitometry using ImageJ software and was normalized to loading controls. Quantification value was expressed as the fold change vs. band numbered 1.0. ImageJ was downloaded from NIH website (http:rsbweb. nih.gov/ij/download.html).

Annexin V-FITC/PI double staining assay. Annexin-V-FLUOS Staining kit was purchased from Roche Diagnostics $\mathrm{GmbH}$ (Penzberg, Germany). Cells were cultured in 6-well plates at cell density of $10^{6}$ cells/well in McCoy's 5A medium and treated with $\mathrm{CRT} 1(10,25$, and $50 \mu \mathrm{M})$ and/or PD98059 $(25 \mu \mathrm{M})$ for $24 \mathrm{~h}$. Cells were centrifuged and washed three times with PBS. Cell pellet was then resuspended in $100 \mu \mathrm{l}$ of Annexin V-FLUOS labeling solution. After incubating at room temperature for $30 \mathrm{~min}$, samples were analyzed on a flow cytometer (BD FACSCanto ${ }^{\mathrm{TM}} \mathrm{II}$; BD Biosciences, Franklin Lakes, NY, USA). 
A

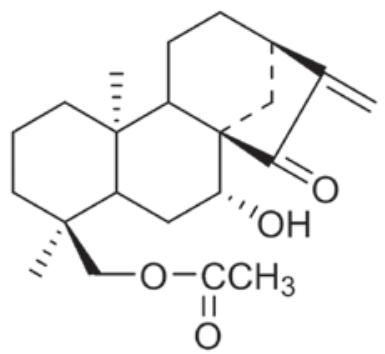

B
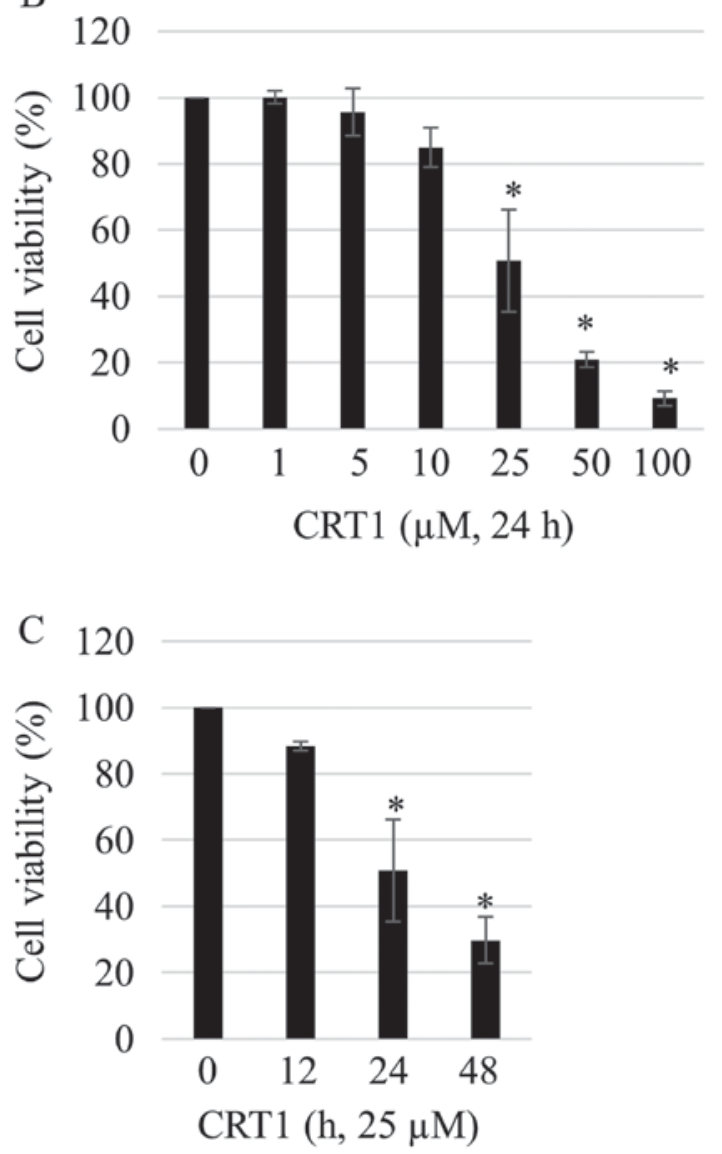

Figure 1. CRT1 decreases the viability of SKOV3 cells. (A) Chemical structure of CRT1. (B) Cells were treated with CRT1 at the indicated concentrations $(1,5,10,25,50$ and $100 \mu \mathrm{M})$ for $24 \mathrm{~h}$. The viability of cells was measured by a CCK-8 assay. (C) Following treatment with CRT1 at $25 \mu \mathrm{M}$ for different time periods $(12,24$ and $48 \mathrm{~h}$ ), cell viability was determined using a CCK- 8 assay. Each assay was performed in triplicate. Data presented as the mean \pm standard deviation. ${ }^{*} \mathrm{P}<0.05$ vs. control $(0 \mu \mathrm{M}$ or $\mathrm{h})$. CRT1 ent-18-acetoxy-7 $\beta$-hydroxy kaur-15-oxo-16-ene; CCK-8, Cell Counting Kit-8.

Soft agar colony forming assay. For determination of anchorage-independent cell growth, $10^{4}$ cells were suspended in growth media supplemented with $10 \% \mathrm{FBS}(3 \mathrm{ml})$ containing $0.3 \%$ agar. They were then applied onto pre-solidified $0.6 \%$ agar $(3 \mathrm{ml})$ in FBS-free growth media in $60 \mathrm{~mm}$ culture dishes. After 2-3 weeks of incubation, colonies on soft agar were observed under a phase-contrast microscope (IX2-ILL100; Olympus Corporation, Tokyo, Japan) and photographed.

Wound healing assay. Cells were seeded into 6-well plates and incubated in serum-free McCoy's 5A for $18 \mathrm{~h}$. The cellular monolayer was wounded with a sterile $10 \mu 1$-pipette tip and washed with serum free McCoy's 5A to remove detached cells from plates. These cells were incubated in the presence or absence of CRT1 for $48 \mathrm{~h}$ in McCoy's 5A containing 10\% FBS. The medium was replaced with PBS and cells were photographed using a phase-contrast microscope (IX2-ILL100; Olympus Corporation).

Matrigel invasion assay. Cell invasion assay was carried out with 24-well flat bottom plate with transparent PET membrane with pore size of $8.0 \mu \mathrm{m}\left(\mathrm{FALCON}^{\circledR}\right.$; Corning Incorporated, Corning, NY, USA). Each insert has been coated with Matrigel Matrix (BD Bioscience, San Jose, CA, USA). Cells $\left(2.5 \times 10^{4}\right)$ suspended in $300 \mu 1$ of serum free McCoy's $5 \mathrm{~A}$ with or without drugs were added to the upper chamber while $500 \mu \mathrm{l}$ of McCoy's 5A containing 10\% FBS were added to the lower chamber of 24-well flat bottom plate. After incubation for $24 \mathrm{~h}$, non-invading cells were removed from the upper surface of the membrane by scrubbing while invading cells on the lower surface of the membrane were stained with hematoxylin. Membranes were then removed and invading cells were counted randomly by light microscopy. Each assay was performed in triplicates and repeated at least three times. Due to variation in the number of migrated cells from different experiment, results were normalized to control cells and relative invasion was expressed as mean $\pm \mathrm{SD}$ of migrating cells relative to control cells.

Statistical analysis. All results presented were confirmed in at least three independent experiments. Data were presented as the mean \pm standard deviation. Statistical differences were analyzed by one-way analysis of variance followed by a Tukey post hoc test using SPSS 24.0 software (IBM Corp., Armonk, NY, USA). $\mathrm{P}<0.05$ was considered to indicate a statistically significant difference.

\section{Results}

CRT1 reduces SKOV3 cellular proliferation in a dose-and time-dependent manner. To evaluate effects of CRT1 on growth, SKOV3 ovarian carcinoma cells were treated with increasing concentrations ( 1 to $100 \mu \mathrm{M}$ ) of CRT1 for various time periods $(12,12$, and $48 \mathrm{~h})$ and cell viabilities were assessed by CCK-8 assay. Viabilities of SKOV3 cells were decreased in a dose- and time-dependent manner after exposure to different concentrations of CRT1 (Fig. 1B and C).

Mitochondrial pathway of apoptosis induced by CRT1 treatment of SKOV3 cells. To investigate the occurrence of apoptosis following CRT1 treatment, flow cytometric analysis was performed using a Annexin V-FITC/PI double staining assay. After SKOV3 cells were treated with 25 and $50 \mu \mathrm{M}$ CRT1 for $24 \mathrm{~h}$, the percentage of Annexin V-positive cells was increased from $0.4 \%$ (in the control) to 29.7 and $57.8 \%$, respectively (Fig. 2A and B). The percentage of necrotic cells was increased from $0.7 \%$ (in the control) to $20.5 \%$ (10 $\mu \mathrm{M}$ CRT1), $20.6 \%$ (25 $\mu \mathrm{M}$ CRT1), and 36.8\% (50 $\mu \mathrm{M}$ CRT1) (Fig. 2A). Effects of CRT1 treatment on the expression of apoptotic proteins, Bax and $\mathrm{Bcl}-2$, were also investigated by western blot analysis. As shown in Fig. 2C, expression levels of proapoptotic protein Bax were significantly increased in SKOV3 cells following treatment with CRT1 at 25 and $50 \mu \mathrm{M}$ for $24 \mathrm{~h}$ compared to those in the control. 
A

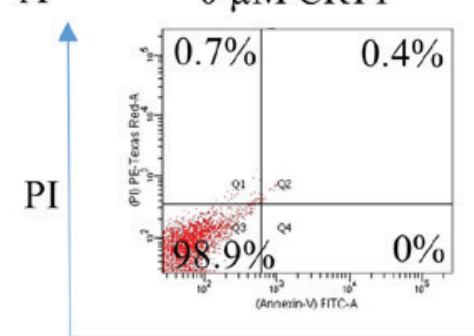

$0 \mu \mathrm{M}$ CRT1

B

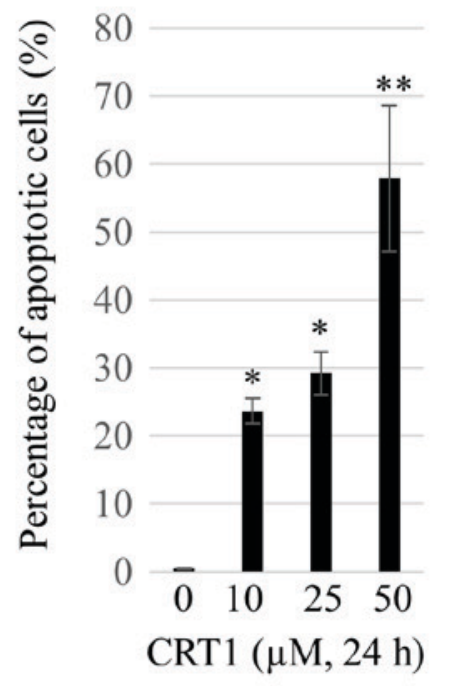

D

$$
\text { CRT1 }(\mu \mathrm{M}, 24 \mathrm{~h})
$$

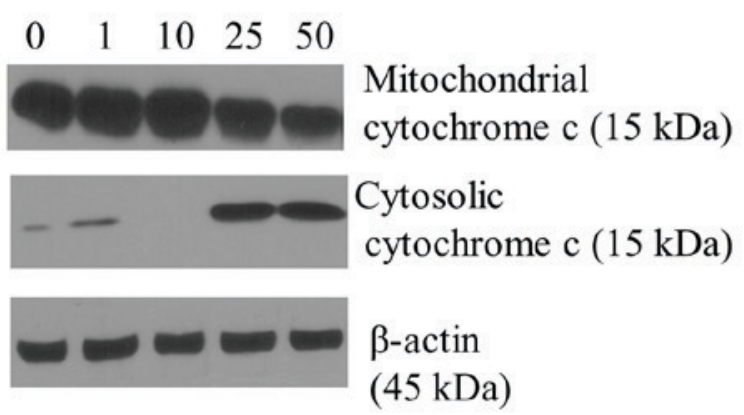

$10 \mu \mathrm{M}$ CRT 1

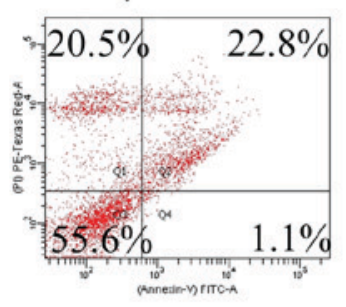

$25 \mu \mathrm{M}$ CRT 1

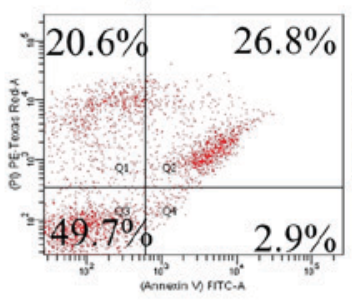

$50 \mu \mathrm{M}$ CRT 1

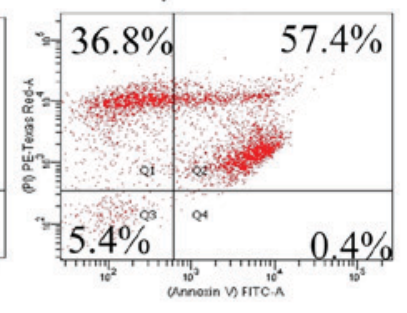

Annexin V

C

CRT1 ( $\mu \mathrm{M}, 24 \mathrm{~h})$
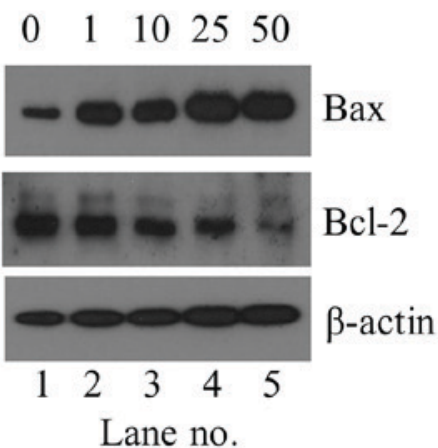
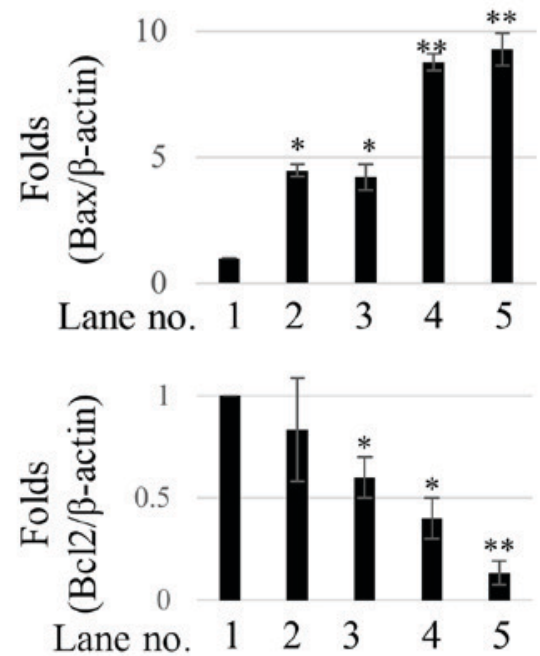

E
CRT1 $(\mu \mathrm{M})$
Z-vad-fmk $(\mu \mathrm{M}) 0$
$\begin{array}{llll}0 & 25 & 50 & 50\end{array}$

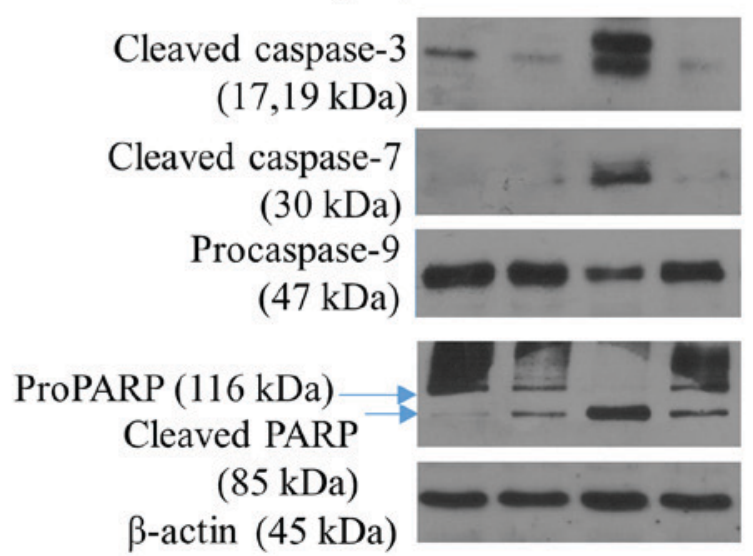

Figure 2. CRT1 induces apoptosis in SKOV3 cells. (A) Cells were treated with CRT1 at 25 or $50 \mu \mathrm{M}$ for $24 \mathrm{~h}$ followed by Annexin V-FITC/PI double staining. Apoptotic cells were analyzed by flow cytometry. Data are representatives of three independent experiments. (B) Percentage of apoptotic cells is presented as the mean \pm standard deviation. ${ }^{*} \mathrm{P}<0.05$ and ${ }^{* *} \mathrm{P}<0.01$ vs. control. (C) Cells were treated with various concentrations of $\mathrm{CRT} 1$ for $24 \mathrm{~h}$ followed by western blot analysis to measure protein expression levels of Bax and Bcl-2. $\beta$-Actin was used as a protein loading control. Protein expression level is presented as the mean \pm standard deviation. ${ }^{*} \mathrm{P}<0.05$ and ${ }^{* *} \mathrm{P}<0.01$ vs. Lane no. 1 . (D) Mitochondria and cytosolic fractions were prepared and western blot analysis was performed to determine cytochrome c levels. (E) Protein levels of caspase-3, -7 and -9 were determined by western blot analysis. Z-VAD-fmk at $100 \mu \mathrm{M}$ was pretreated for $2 \mathrm{~h}$ followed by CRT1 treatment for an additional $24 \mathrm{~h}$. CRT1, ent-18-acetoxy-7 $\beta$-hydroxy kaur-15-oxo-16-ene; FITC, fluorescein isothiocyanate; PI, propidium iodide; Bcl-2, B-cell lymphoma 2; Bax, Bcl-2-associated X protein; PARP, poly-(adenosine diphosphate-ribose) polymerase.

However, expression levels of anti-apoptotic protein Bcl-2 were decreased in cells treated with CRT1 at 25 and $50 \mu \mathrm{M}$ for $24 \mathrm{~h}$ compared to those in the control. Bax is a key proapoptotic molecule in the mitochondrially mediated apoptotic pathway. It is responsible for pore-opening of the mitochondria to release cytochrome c and activate caspase family of proteases as part of the apoptotic cascade (21). Therefore, we examined the effect of CRT1 on the release of cytochrome $\mathrm{c}$ and caspase-3, $-7,-9$, and
poly(ADP-ribose) polymerase (PARP) activation. CRT1 significantly enhanced cytochrome c release from the mitochondria to the cytosol (Fig. 2D), leading to increased expression of cleaved caspase-3, cleaved caspase-7, and cleaved PARP but decreased expression of procaspase-9 compared with the control (Fig. 2E). Pretreatment of SKOV3 cells with z-VAD-fmk, a caspase inhibitor, attenuated the ability of CRT1 to activate the caspase cascade (Fig. 2E). 
A CRT1 $(\mu \mathrm{M}, 24 \mathrm{~h})$
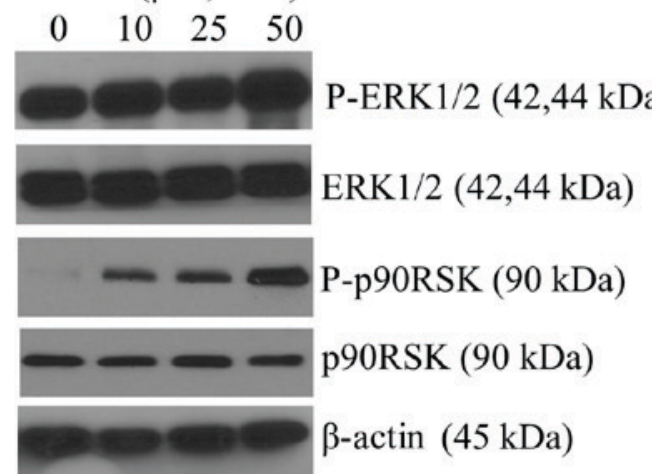

Lane no. $1 \quad 2 \quad 3 \quad 4$

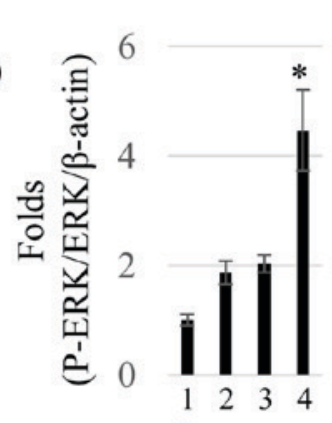

Lane no.

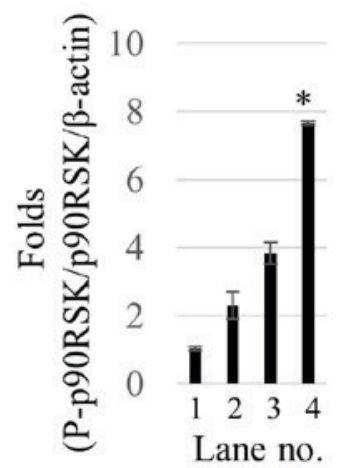

B

$$
\text { CRT1 (h, } 50 \mu \mathrm{M})
$$
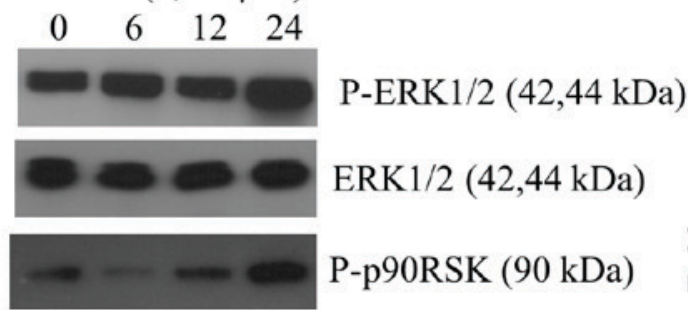

P-p90RSK (90 kDa)

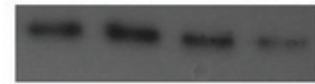

p90RSK $(90 \mathrm{kDa})$

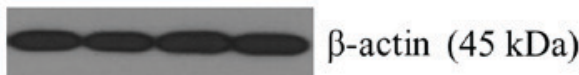

Lane no. $1 \quad 2 \quad 3 \quad 4$
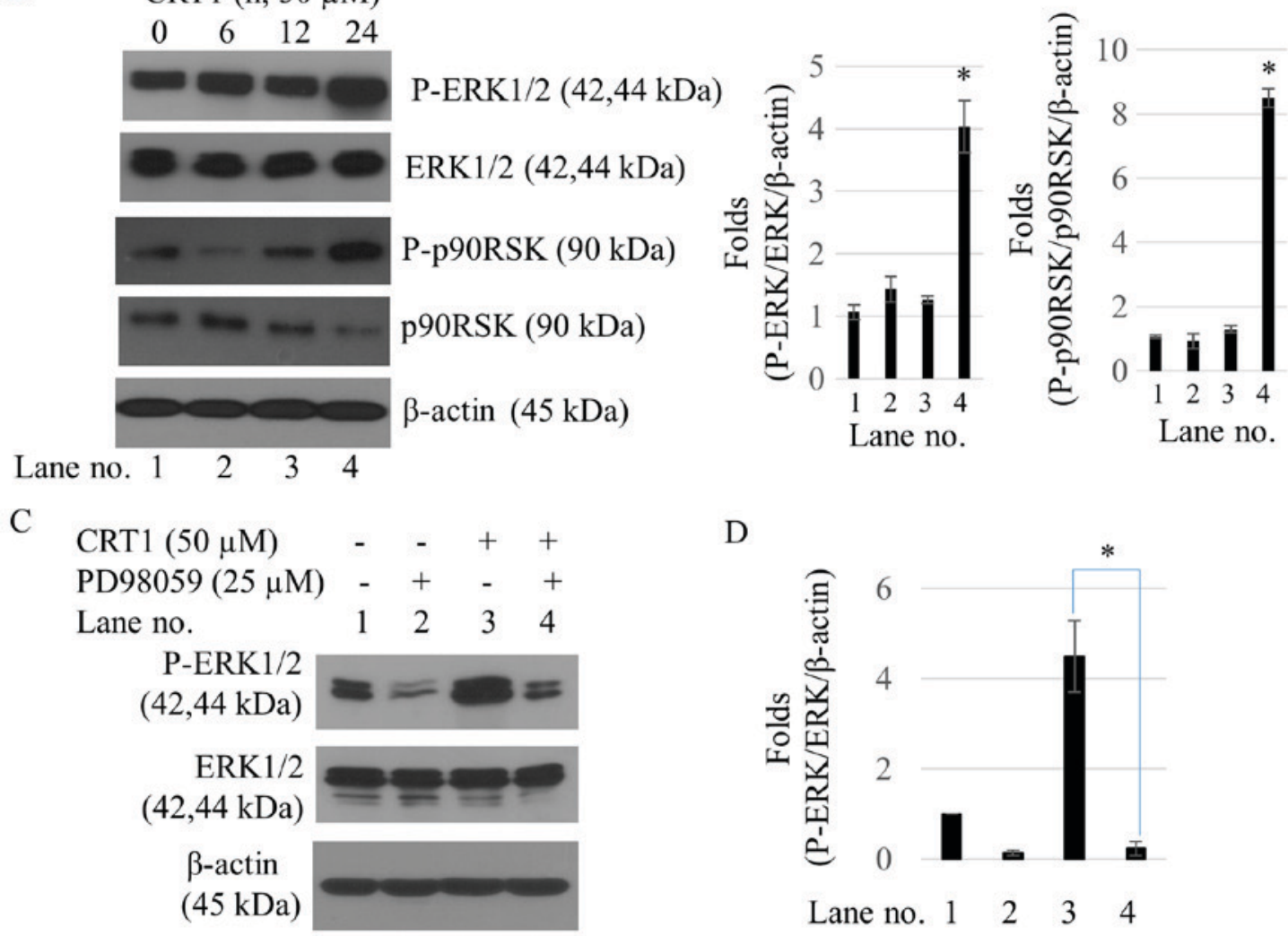

D

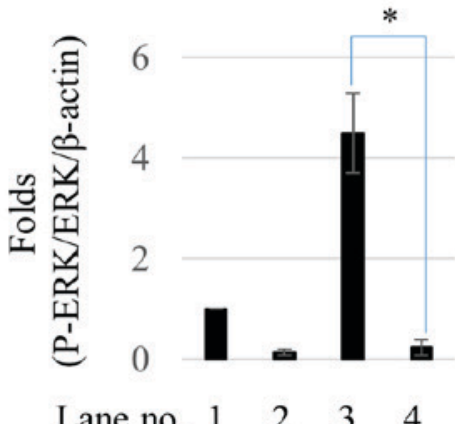

Figure 3. Effect of CRT1 on ERK1/2 phosphorylation in SKOV3 cells. (A) Time-dependent and (B) concentration-dependent effects of CRT1 on the protein expression levels of ERK1/2, p-ERK1/2, p90RSK and p-p90RSK were analyzed by western blotting. Actin was used as a protein loading control. Each experiment was performed in triplicate. All data are presented as the mean \pm standard deviation. ${ }^{*} \mathrm{P}<0.05$ vs. the control. (C) ERK inhibitor PD98059 reversed the CRT1-induced phosphorylation of ERK1/2. PD98059 $(25 \mu \mathrm{M})$ was preincubated for $2 \mathrm{~h}$ prior to the addition of CRT1 (50 $\mu \mathrm{M})$. Phosphorylation levels of ERK1/2 and total ERK, and the expression level of actin were analyzed by western blot analysis with the indicated antibodies. (D) Protein expression level is presented as the mean \pm standard deviation. ${ }^{*} \mathrm{P}<0.05$ vs. Lane no. 3. CRT1, ent-18-acetoxy-7 $\beta$-hydroxy kaur-15-oxo-16-ene; ERK, extracellular signal-regulated kinase; p-, phosphorylated.

CRT1 increases ERK/p90RSK phosphorylation of SKOV3 cells. To determine whether the MAPK/ERK1/2 pathway was involved in the anticancer effect of CRT1, this study examined phosphorylation of ERK1/2 and its substrate, p90RSK, following treatment with CRT1. CRT1 significantly increased phosphorylation levels of ERK1/2 at Thr202/Tyr204 sites and p90RSK at Ser380 site in a dose- and time-dependent manner. However, there was no significant difference in total expression levels of ERK1/2 and p90RSK proteins between control and CRT1 treatment (Fig. 3A and B). PD98059, a specific ERK inhibitor, failed to increase CRT1-induced
ERK1/2 activation (Fig. 3C) or suppress CRT1-induced cell viability (Fig. 3D).

CRT1-induced anti-proliferation and apoptosis is reversed by ERK inhibitor. To study whether ERK1/2 was involved in CRT1-induced apoptosis of SKOV3 cells, PD98059, a specific ERK inhibitor, was used. PD98059 treatment failed to increase CRT1-induced caspase-3, caspase-7, and PARP cleavages (Fig. 4A) or the percentage of annexin V-positive cells (Fig. 4B and C). To evaluate the reversed effect of PD98059 on CRT1-induced cell growth, viability of SKOV3 cells 
A

$\begin{array}{llllll}\text { CRT1 }(50 \mathrm{uM}) & - & - & + & + \\ \text { PD98059 }(25 \mu \mathrm{M}) & - & + & - & +\end{array}$

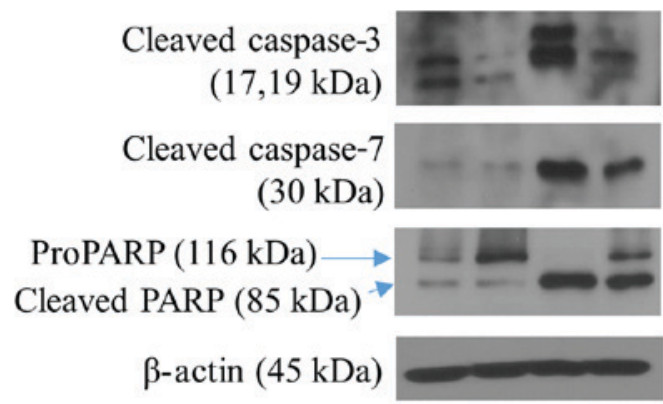

C

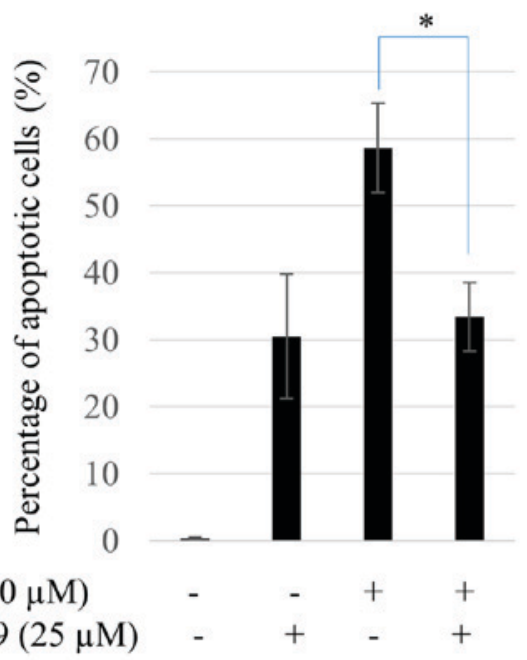

B

a

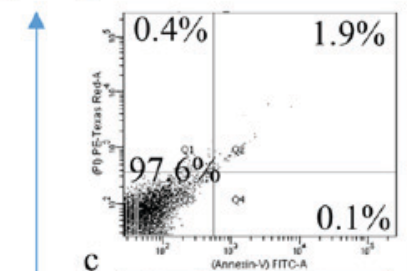

b

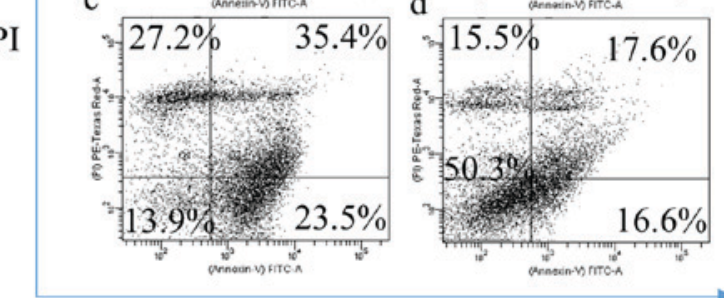

Annexin V

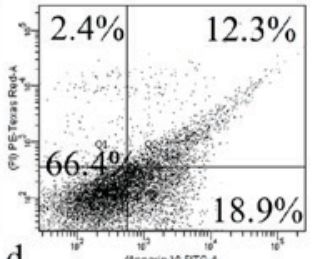

$\begin{array}{ll}\text { a } & \text { CRT1 }(0 \mu \mathrm{M}) \\ \text { b } & \text { PD98059 }(25 \mu \mathrm{M})\end{array}$

c $\quad$ CRT1 $(50 \mu \mathrm{M})$

d CRT1 $(50 \mu \mathrm{M})+$ PD98059 $(25 \mu \mathrm{M})$

$\mathrm{D}$
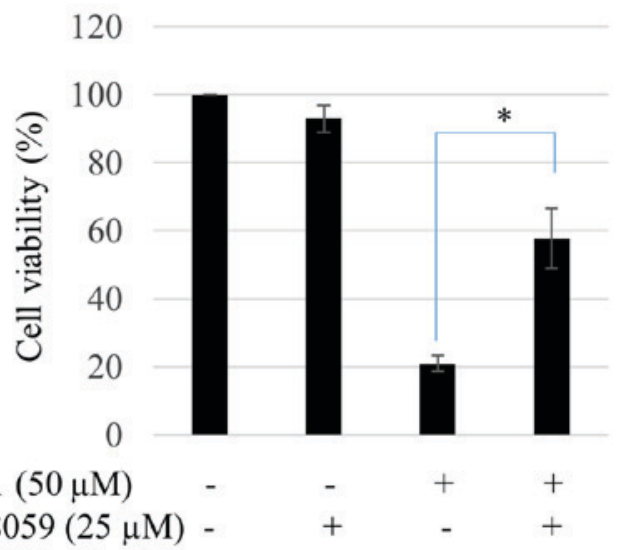

Figure 4. ERK1/2 regulates CRT1-induced apoptosis and anti-proliferation. (A) ERK inhibitor PD98059 reversed CRT1-induced caspase cleavages. PD98059 $(25 \mu \mathrm{M})$ was preincubated for $2 \mathrm{~h}$ prior to the addition of CRT1 $(50 \mu \mathrm{M})$. Levels of cleaved caspase-3, caspase-7, PARP and $\beta$-actin were analyzed using western blot analysis with the indicated antibodies. (B) Cells were pretreated with PD98059 for $2 \mathrm{~h}$ prior to CRT1 $(50 \mu \mathrm{M})$ treatment. Apoptotic cells were analyzed by Annexin V-FITC/PI double staining assay followed by flow cytometry. Data are representatives of three independent experiments. (C) Percentage of apoptotic cells. (D) Following pre-incubation of PD98059 prior to CRT1 treatment $(50 \mu \mathrm{M})$, cell viability was determined using Cell Counting Kit-8 assay. Each assay was performed in triplicate. Data are presented as the mean \pm standard deviation. "P $<0.05$ vs. CRT1 single treatment. ERK, extracellular signal-regulated kinase; CRT1, ent-18-acetoxy-7 $\beta$-hydroxy kaur-15-oxo-16-ene; PARP, poly-(adenosine diphosphate-ribose) polymerase; FITC, fluorescein isothiocyanate; PI, propidium iodide.

was assessed by CCK8 cell-counting assay. CRT1 failed to decrease cell viability following pretreatment of SKOV3 cells with PD98059 (Fig. 4D).

CRT1 inhibits migration and invasion through ERK1/2 activation in SKOV3 cells. Results from colony survival assays of CRT1 are presented as photographs. Results showed that activation of ERK1/2 by $50 \mu \mathrm{M}$ CRT1 treatment strongly diminished colony sizes (Fig. 5A). To evaluate the effect of CRT1 on cell migration, wound healing assay and transwell migration assay were performed. Results showed that CRT1 $(50 \mu \mathrm{M})$ suppressed the migration of SKOV3 cells (Fig. 5B). Consistent with this result, transwell invasion assay also showed that $50 \mu \mathrm{M}$ CRT1 significantly weakened the invasion capacity of SKOV3 cells (Fig. 5C and D). To investigate whether ERK1/2 was involved in CRT1-induced metastasis of
SKOV3 cells, PD98059, a specific ERK inhibitor, was used in the experiment. PD98059 reversed CRT1-induced migration and invasion (Fig. 5B-D) as well as colony-forming ability (Fig. 5A).

\section{Discussion}

A variety of substances such as those present in dietary and medicinal plants all over the world have inhibitory effects on several cancers. The genus Croton consists of about 800 species that are widely distributed throughout tropical and subtropical regions. About 31 of these medicinal plant species are cultivated or grow wild in northern Vietnam (9). An ent-18-acetoxy-7 $\beta$-hydroxy kaur-15-oxo-16-ene is one of main substances isolated from Croton tonkinensis. A prior report has shown that this ent-kaurane diterpenoid compound can regulate 
A
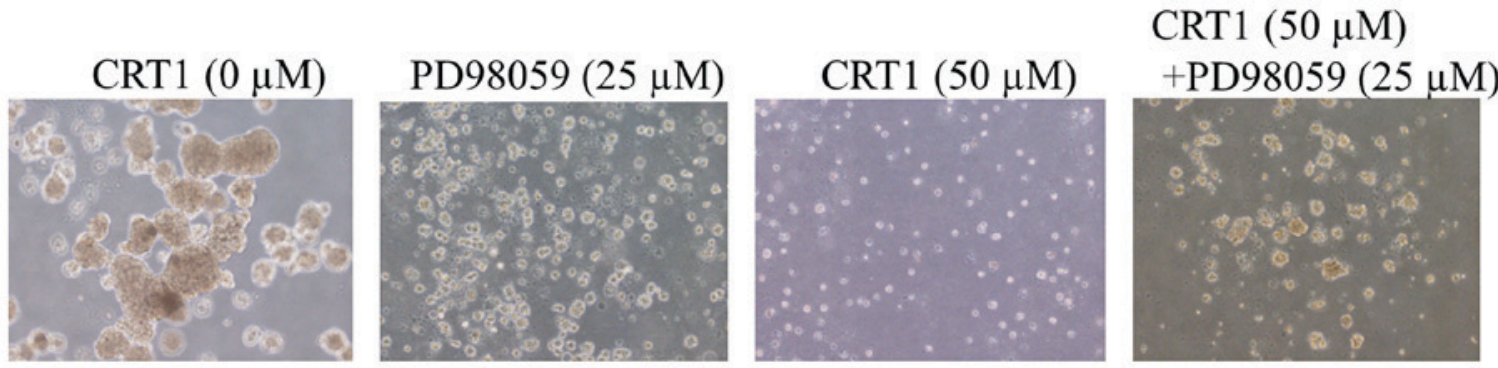

$\mathrm{B}$
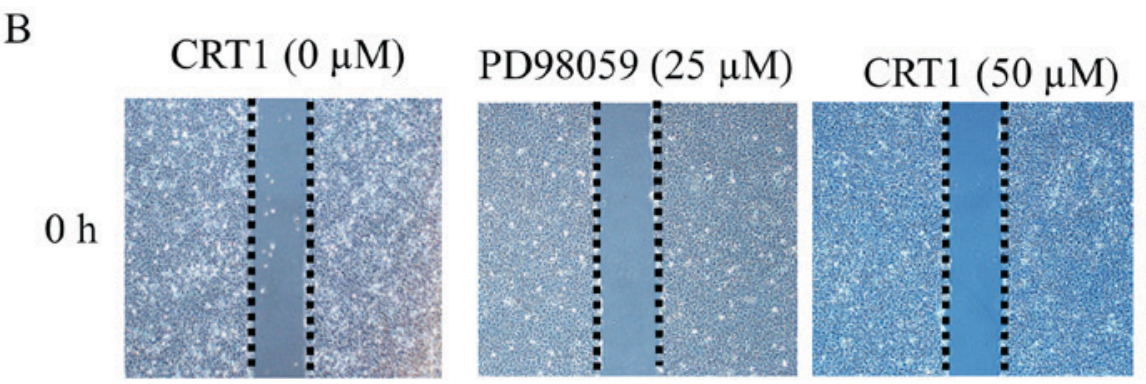

CRT1 $(50 \mu \mathrm{M})$
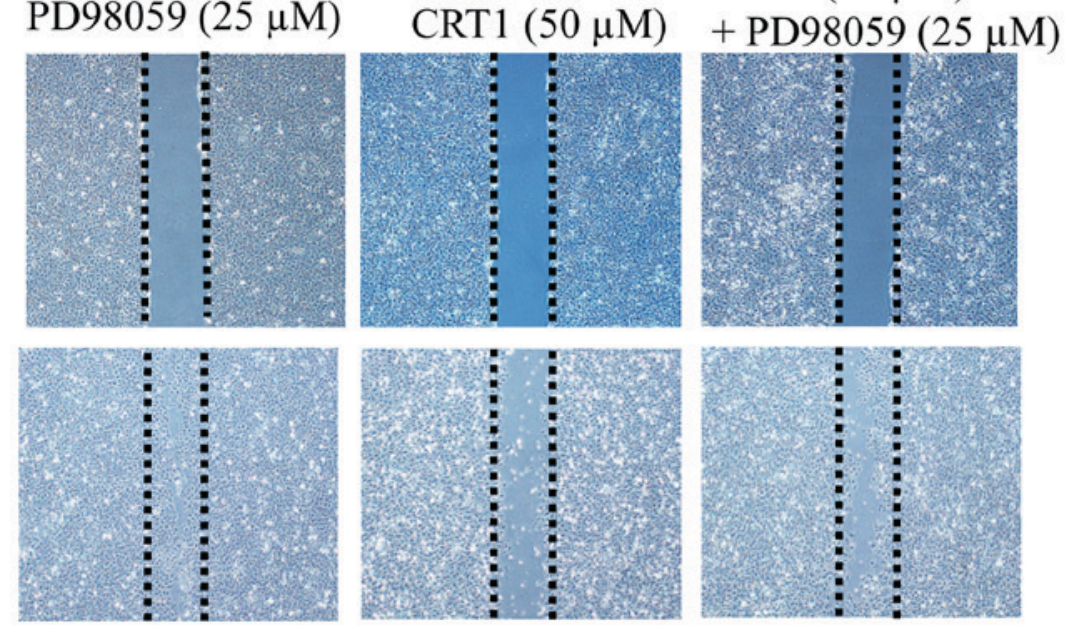

$48 \mathrm{~h}$

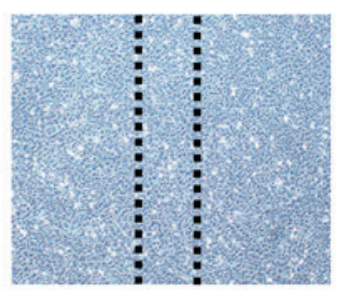

$\operatorname{PD} 98059(25 \mu \mathrm{M})$

$\mathrm{D}$

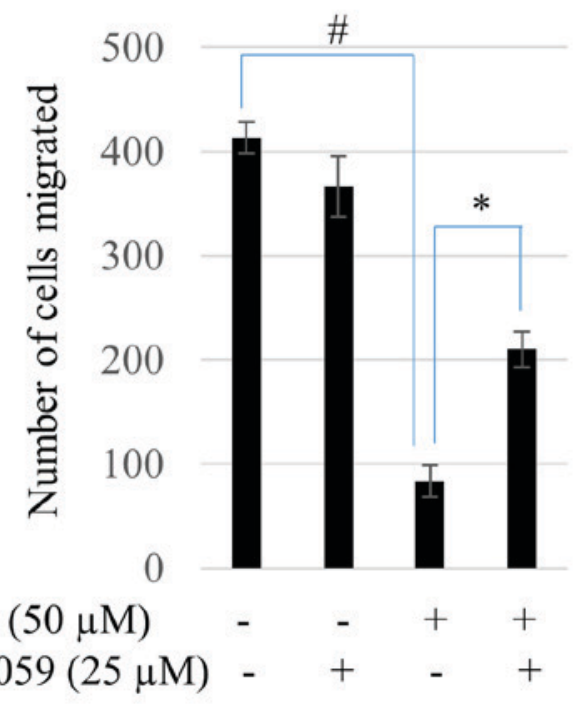

Figure 5. CRT1 inhibits colony-forming ability, cell migration and invasion of SKOV3 cells by ERK activation. (A) Colony-forming assay for single cell culture of SKOV3 cells treated with CRT1 $(50 \mu \mathrm{M})$ and/or PD98059 $(25 \mu \mathrm{M})$. Cells were allowed to culture until visible colonies were evident. Data are presented as photographs: Phase-contrast microscopic examination of the morphology of cells in culture (magnification, x100). (B) Cell migration was measured by wound healing assay. Cells in culture were wounded and allowed to migrate into the denuded area for $48 \mathrm{~h}$. Five random views were chosen along the scratch wound in each well (magnification, x100). (C) Transwell invasion assay. CRT1 $(50 \mu \mathrm{M})$ and/or PD98059 (25 $\mu \mathrm{M})$-treated cells were fixed and stained following $48 \mathrm{~h}$ as described in the materials and methods. Three randomly selected fields of view were photographed in each well (magnification, x100). (D) Quantification of the migration of SKOV3 cells. Data represent replicates of three independent experiments and are expressed as the mean \pm standard deviation. ${ }^{*} \mathrm{P}<0.05$ vs. CRT1 single treatment; ${ }^{\mathrm{P}} \mathrm{P}<0.05$ vs. untreated control. CRT1, ent-18-acetoxy-7 $\beta$-hydroxy kaur-15-oxo-16-ene; ERK, extracellular signal-regulated kinase.

cell viability of SK-HEP1 hepatoma cancer cell line at $\mathrm{IC}_{50}$ of $<5 \mu \mathrm{M}$ (18). Another ent-kaurane diterpenoid compound, oridonin, can suppress the proliferation of human ovarian cancer cells such as SKOV3, OVCAR-3 and A2780 cells at $\mathrm{IC}_{50}$ values of $17.21,13.9$, and $12.1 \mu \mathrm{M}$, respectively (22). Our results showed that CRT1, an ent-kaurane diterpenoid compound, significantly reduced proliferation of SKOV3 ovarian cancer cells, with $\mathrm{IC}_{50}$ value of $24.6 \mu \mathrm{M}$ (Fig. 1A). Several papers have suggested that ent-kaurane diterpenoid possesses apoptotic effects on various cancers such as colorectal carcinoma, pancreatic adenocarcinoma, esophageal squamous cell carcinoma, hepatocellular carcinoma, and ovarian cancer (23-26). Consistent with these reports, our study showed that CRT1 increased apoptosis of SKOV3 cells (Fig. 2). Besides, the percentages of necrotic cells 
increased after treatment, suggesting that CRT1 could induce necrosis in SKOV3 cells (Fig. 2A). Prior reports have indicated that ent-kaurane diterpenoids can produce antiproliferation effects on cancer cells by induction of apoptosis as well as necrosis $(27,28)$.

To further understand the mechanisms in the anticancer activity of CRT1 against ovarian cancer, we analyzed the effect of CRT1 on ERK1/2/p90RSK signaling pathway. Mitogen-activated protein kinases (MAPKs) are a family of serine/threonine protein kinases that include ERK, JNK, and p38. These kinases are involved in the activation of nuclear transcription factors that control cellular proliferation, cell cycle progression, apoptosis, and cell migration (29). RSKs, a family member of serine/threonine protein kinases, are activated by ERK1/2 in response to many growth factors and hormones. ERK/1/2/p90RSK pathway is known to modulate a variety of cellular processes, including cell proliferation, survival, motility, and invasiveness in ovarian cancers (30-32). However, how this pathway activates proapoptotic signaling remains largely unknown. Oridonin, one ent-kaurane diterpenoid, has been previously reported to be able to induce phosphorylation of ERK, JNK, and p38 MAPK (33). Our study revealed that CRT1 dramatically increased phosphorylation level of ERK1/2 in a dose-dependent (Fig. 3A) and time-dependent (Fig. 3B). However, no significant activation of JNK or p38 was observed under the same condition (data not shown). A specific ERK inhibitor, PD98059, prevented the activation of ERK1/2 in CRT1-induced cells (Fig. 3C and D). Moreover, PD98059 blocked CRT1-mediated increase in cell growth (Fig. 4D) and apoptosis (Figs. 4A-C). These results strongly support that CRT1-induced anticancer activities are regulated by ERK1/2 activation in SKOV3 ovarian cancer cells. A prior report has suggested that ERK1/2 and p90RSK signaling can dynamically regulate cell motility in cancers (34). We were interested in investigating the role of ERK1/2 activation in SKOV3 cells in relation to colony formation, migration, and invasion. Our results revealed that CRT1-induced ERK1/2 activation inhibited ovarian cancer cell metastasis while ERK inhibitor PD98059 prevented CRT1-induced anti-migration and anti-invasive activity of SKOV3 cells (Fig. 5). These results suggest that CRT1 plays an important role in cell proliferation, migration, and the invasive potential of ovarian cancer cells via ERK1/2 activation.

Primary cells are believed to be more biologically relevant tools than cell lines for studying cancer biology (35). Cell lines are known to grow faster with minimal care. There is a possibility that cell lines do not behave identically with primary cells. They should not be used to replace primary cells (35). Although this study was performed with SKOV3 cell line, we should do confirmation with primary cells in the future.

Overall, our study showed that CRT1 could inhibit cell viability, cell migration, and invasion of SKOV3 ovarian cancer cells through activating the ERK1/2/p90RSK signaling pathway. These results indicate that a natural ent-kaurane diterpenoid, CRT1, might have potential as a chemotherapeutic agent to prevent the spread of ovarian cancer by activating ERK1/2. Further studies are needed to investigate the biological efficacy of CRT1 for treating ovarian cancer using in vivo model.

\section{Acknowledgements}

Not applicable.

\section{Funding}

The present study was supported by a research fund from Chungnam National University (grant no. 2015-0881-01).

\section{Availability of data and materials}

All data generated or analyzed during this study are included in this published article.

\section{Authors' contributions}

JSL designed the study and prepared the manuscript. MSL, EYC and JBP performed the experiments and analyzed the data. PTT isolated and identified the structure of CRT1. JYS and YBK conceived and designed the study, and revised the manuscript.

\section{Ethics approval and consent to participate}

Not applicable.

\section{Patient consent for publication}

Not applicable.

\section{Competing interests}

The authors declare that they have no competing interests.

\section{References}

1. Serkies K, Węgrzynowicz E and Jassem J: Paclitaxel and cisplatin chemotherapy for ovarian cancer during pregnancy: Case report and review of the literature. Arch Gynecol Obstet 283 (Suppl 1): S97-S100, 2011.

2. Wen W, Wu J, Liu L, Tian Y, Buettner R, Hsieh MY, Horne D, Dellinger TH, Han ES, Jove R and Yim JH: Synergistic anti-tumor effect of combined inhibition of EGFR and JAK/STAT3 pathways in human ovarian cancer. Mol Cancer 14: 100, 2015

3. Vaughan S, Coward JI, Bast RC Jr, Berchuck A, Berek JS, Brenton JD, Coukos G, Crum CC, Drapkin R, Etemadmoghadam D, et al: Rethinking ovarian cancer: Recommendations for improving outcomes. Nat Rev Cancer 11: 719-725, 2011.

4. Lu Z and Xu S: ERK1/2 MAP kinases in cell survival and apoptosis. IUBMB Life 58: 621-631, 2006.

5. Cagnol S and Chambard JC: ERK and cell death: Mechanisms of ERK-induced cell death-apoptosis, autophagy and senescence. FEBS J 277: 2-21, 2010.

6. Calvo N, Carriere P, Martin MJ and Gentili C: RSK activation via ERK modulates human colon cancer cells response to PTHrP. J Mol Endocrinol 59: 13-27, 2017.

7. Giang PM, Son PT, Lee JJ and Otsuka H: Four ent-kaurane-type diterpenoids from Croton tonkinensis Gagnep. Chem Pharm Bull (Tokyo) 52: 879-882, 2004.

8. Do TL: Medicinal plants and remedies of Vietnam; Publishing House Medicine, Hanoi, pp826-828, 2001.

9. Kuo PC, Shen YC, Yang ML, Wang SH, Thang TD, Dung NX Chiang PC, Lee KH, Lee EJ and Wu TS: Crotonkinins A and B and related diterpenoids from Croton tonkinensis as anti-inflammatory and antitumor agents. J Nat Prod 70: 1906-1909, 2007.

10. Phan MG, Phan TS, Hamada Y and Otsuka H: Cytotoxic diterpenoids from Vietnamese medicinal plant Croton tonkinensis GAGNEP. Chem Pharm Bull (Tokyo) 53: 296-300, 2005. 
11. Thuong PT, Khoi NM, Ohta S, Shiota S, Kanta H, Takeuchi K and Ito F: ent-kaurane diterpenoids from Croton tonkinensis induce apoptosis in colorectal cancer cells through the phosphorylation of JNK mediated by reactive oxygen species and dual-specificity JNK kinase MKK4. Anticancer Agents Med Chem 14: 1051-1061, 2014.

12. Giang PM, Jin HZ, Son PT, Lee JH, Hong YS and Lee JJ: ent-Kaurane diterpenoids from croton tonkinensis inhibit LPS-induced NF-kappaB activation and NO production. J Nat Prod 66: 1217-1220, 2003.

13. Thuong PT, Dao TT, Pham TH, Nguyen PH, Le TV, Lee KY and Oh WK: Crotonkinensins A and B, diterpenoids from the Vietnamese medicinal plant Croton tonkinensis: J Nat Prod 72: 2040-2042, 2009.

14. Dao TT, Le TV, Nguyen PH, Thuong PT, Minh PT, Woo ER, Lee KY and Oh WK: SIRT1 inhibitory diterpenoids from the Vietnamese medicinal plant Croton tonkinensis. Planta Med 76: 1011-1014, 2010.

15. Dao TT, Lee KY, Jeong HM, Nguyen PH, Tran TL, Thuong PT, Nguyen BT and Oh WK: ent-Kaurane diterpenoids from Croton tonkinensis stimulate osteoblast differentiation. J Nat Prod 74 2526-2531, 2011

16. Lu J, Chen X, Qu S, Yao B, Xu Y, Wu J, Jin Y and Ma C: Oridonin induces $\mathrm{G}_{2} / \mathrm{M}$ cell cycle arrest and apoptosis via the PI3K/Akt signaling pathway in hormone-independent prostate cancer cells. Oncol Lett 13: 2838-2846, 2017.

17. Deng R, Tang J, Xia LP, Li DD, Zhou WJ, Wang LL, Feng GK, Zeng YX, Gao YH and Zhu XF: ExcisaninA, a diterpenoid compound purified from Isodon MacrocalyxinD, induces tumor cells apoptosis and suppresses tumor growth through inhibition of PKB/AKT kinase activity and blockade of its signal pathway. Mol Cancer Ther 8: 873-882, 2009.

18. Sul YH, Lee MS, Cha EY, Thuong PT, Khoi NM and Song IS: An ent-kaurane diterpenoid from Croton tonkinensis induces apoptosis by regulating AMP-activated protein kinase in SK-HEP1 human hepatocellular carcinoma cells. Biol Pharm Bull 36: $158-164,2013$

19. Ye Q, Yao G, Zhang M, Guo G, Hu Y, Jiang J, Cheng L, Shi J, $\mathrm{Li} \mathrm{H}$, Zhang $\mathrm{Y}$ and Liu H: A novel ent-kaurane diterpenoid executes antitumor function in colorectal cancer cells by inhibiting Wnt/ $\beta$-catenin signaling. Carcinogenesis 36: 318-326, 2015

20. Zhou X, Yue GG, Chan AM, Tsui SK, Fung KP, Sun H, Pu J and Lau CB: Eriocalyxin B, a novel autophagy inducer, exerts anti-tumor activity through the suppression of Akt $/ \mathrm{mTOR} / \mathrm{p} 70 \mathrm{~S} 6 \mathrm{~K}$ signaling pathway in breast cancer. Biochem Pharmacol 142 : 58-70, 2017.

21. Chipuk JE, Kuwana T, Bouchier-Hayes L, Droin NM Newmeyer DD, Schuler M and Green DR: Direct activation of Bax by p53 mediates mitochondrial membrane permeabilization and apoptosis. Science 303: 1010-1014, 2004

22. Xia R, Chen SX, Qin Q, Chen Y, Zhang WW, Zhu RR and Deng AM: Oridonin suppresses proliferation of human ovarian cancer cells via blockage of mTOR signaling. Asian Pac J Cancer Prev 17: 667-671, 2016.
23. Qiu S, Wu X, Liao H, Zeng X, Zhang S, Lu X, He X, Zhang X, Ye W, Wu H and Zhu X: Pteisolic acid G, a novel ent-kaurane diterpenoid, inhibits viability and induces apoptosis in human colorectal carcinoma cells. Oncol Lett 14: 5540-5548, 2017.

24. Li L, Yue GG, Lau CB, Sun H, Fung KP, Leung PC, Han Q and Leung PS: Eriocalyxin B induces apoptosis and cell cycle arrest in pancreatic adenocarcinoma cells through caspase- and p53-dependent pathways. Toxicol Appl Pharmacol 262: 80-90, 2012.

25. Yao R, Chen Z, Zhou C, Luo M, Shi X, Li J, Gao Y, Zhou F, Pu J, Sun $\mathrm{H}$ and He J: Xerophilusin B induces cell cycle arrest and apoptosis in esophageal squamous cell carcinoma cells and does not cause toxicity in nude mice. J Nat Prod 78: 10-16, 2015.

26. Liao YJ, Bai HY, Li ZH, Zou J, Chen JW, Zheng F, Zhang JX, Mai SJ, Zeng MS, Sun HD, et al: Longikaurin A, a natural ent-kaurane, induces $\mathrm{G} 2 / \mathrm{M}$ phase arrest via downregulation of Skp2 and apoptosis induction through ROS/JNK/c-Jun pathway in hepatocellular carcinoma cells. Cell Death Dis 5: e1137, 2014.

27. Liu JJ, Huang RW, Lin DJ, Wu XY, Peng J, Pan XL, Lin Q, Hou M, Zhang MH and Chen F: Antiproliferation effects of oridonin on HPB-ALL cells and its mechanisms of action. Am J Hematol 81: 86-94, 2006.

28. Liu GA, Chang JC, Feng XL and Ding L: Apoptosis induced by weisiensin B isolated from Rabdosia weisiensis C.Y. Wu in K562. Pharmazie 70: 263-268, 2015.

29. Miller CR, Oliver KE and Farley JH: MEK1/2 inhibitors in the treatment of gynecologic malignancies. Gynecol Oncol 133: 128-137, 2014.

30. Torchiaro E, Lorenzato A, Olivero M, Valdembri D, Gagliardi PA, Gai M, Erriquez J, Serini G and Di Renzo MF: Peritoneal and hematogenous metastases of ovarian cancer cells are both controlled by the p90RSK through a self-reinforcing cell autonomous mechanism. Oncotarget 7: 712-728, 2016

31. Kim JH, Jeong SJ, Kim B, Yun SM, Choi DY and Kim SH: Melatonin synergistically enhances cisplatin-induced apoptosis via the dephosphorylation of ERK/p90 ribosomal S6 kinase/heat shock protein 27 in SK-OV-3 cells. J Pineal Res 52: 244-252, 2012.

32. Bai RX, Wang WP, Zhao PW and Li CB: Ghrelin attenuates the growth of HO-8910 ovarian cancer cells through the ERK pathway. Braz J Med Biol Res 49: pii: S0100-879X2016000300602, 2016.

33. Kuo LM, Kuo CY, Lin CY, Hung MF, Shen JJ and Hwang TL: Intracellular glutathione depletion by oridonin leads to apoptosis in hepatic stellate cells. Molecules 19: 3327-3344, 2014.

34. Tanimura $\mathrm{S}$ and Takeda $\mathrm{K}$ : ERK signalling as a regulator of cell motility. J Biochem 162: 145-154, 2017.

35. Kaur G and Dufour JM: Cell lines: Valuable tools or useless artifacts. Spermatogenesis 2: 1-5, 2012.

(i) $(-)$ This work is licensed under a Creative Commons Attribution-NonCommercial-NoDerivatives 4.0 International (CC BY-NC-ND 4.0) License. 